\title{
Pelatihan Dan Pendampingan Dalam Pengabdian Dan Pendampingan Pemasaran Produk Hasil Homemade Dengan Media Sosial Di Desa Deketagung Kecamatan Sugio Kabupaten Lamongan
}

\author{
Sutri Handayani, Abdul Ghofur, Dwi Nur Fadhilah \\ Fakultas Ekonomi Universitas Islam Lamongan, \\ Email: sutrihandayani99@gmail.com, \\ abdulghofur@unisla.ac.id, \\ dwinurfadhila@gmail.com.
}

\begin{abstract}
ABSTRAK
Produk homemade yang sudah dihasilkan oleh masyarakat di Desa Deketagung seluruhnya adalah produk makanan buatan sendiri dengan teknologi sederhana yang berskala rumahan dan dikerjakan oleh para ibu-ibu rumah tangga. banyaknya kendala yang dialami dalam pertumbuhan usaha homemade yang ada di Desa Deketagung yang diproduksi oleh ibu-ibu rumah tangga, sehingga masih kurang optima dalam penjualannya. Strategi pemasaran yang dijadikan sebagai solusi adalah berbasis teknologi, yang akan menjadi kekuatan dalam mendongkrak penjualan produk homemade. Tujuan dari kegiatan ini yaitu untuk meningkatkan pangsa pasar produk homemade sehingga dapat meningkatkan omset dan laba penjualan produk dengan menggunakan media sosial sebagai alat pemasarannya. Kelompok peserta berjumlah 30 Orang, yang terdiri dari bermacam-macam jenis produk homemade di Desa Deketagung yang paling banyak yaitu ibu rumah tangga. Metode yang digunakan dalam kegiatan ini adalah Pelatihan dan pendampingan dalam pengabdian dan pendampingan kepada pelaku usaha homemade. Hasil Pelatihan dan pendampingan dalam pengabdian dalam kegiatan ini yaitu adanya peningkatan dari pengetahuan dan kemampuan peserta dalam memanfaatkan media sosial untuk dijadikan sebagai alat pemasaran, dimana ini ditunjukkan dengan adanya perubahan angka rerata pretest dan post tes, seperti nilai dari skor 72 ke skor 100. Pemahaman terakhir dari setiap peserta terhadap media sosial instagram diperoleh sebesar $75 \%$ lebih besar dari pada pemahaman terakhir dari peserta terhadap website toko online sebesar $65 \%$.
\end{abstract}

Kata Kunci : Media Sosial, Pelatihan dan Pengabdian, Pendapingan, Produk Homemade

\section{PENDAHULUAN}

Usaha UMKM memiliki peranan penting dalam perekonomian Indonesia dimana pada masa covid-19 ini bukan hanya usaha homemade saja yang terdampak meliankan perusahaan besar juga mengalami keruntuhan, namun usaha homemade dapat bertahan dan jadi penggerak dalam perekonomian Indonesia. Peran penting yang ada pada usaha homemade dalam pembangunan ekonomi nasional yaitu berkontribusi untuk pertumbuhan ekonomi nasional dan penyerapan SDM sebagai tenaga kerja, usaha homemade juga berperan dalam pendistribusian untuk menghasilkan pembangunan yang berkelanjutan dan sebagai motor penggerak pertumbuhan aktivitas ekonomi nasional.

Usaha rumah tangga dapat meningkatkan jumlah unit usaha dan mendukung peningkatan pendapatan keluarga. Masa Covid-19 yang terjadi ternyata telah membuka cakrawala bangsa Indonesia tentang rapuhnya sistem ekonomi yang dibangun. Usaha-usaha untuk meningkatkan daya saing USAHA HOMEMADE perlu dilakukan pemerintah untuk meningkatkan pertumbuhan ekonominya. Kenyataan mengatakan bahwa suatu perekonomian yang ditopang oleh keberadaan USAHA HOMEMADE terbukti bertahan terhadap masalah pada stabilitas perekonomian. Ada beberapa sektor yang dapat dijadikan pedoman bagi 
seluruh daerah untuk meningkatkan pendapatan pertumbuhan ekonomi daerahnya. Sektor pengembangan USAHA HOMEMADE yang berwawasan lokal adalah pilihan terbaik. Pemerintah gencar menggalakkan program pendampingan dan Pelatihan dan pendampingan dalam pengabdian bagi masyarakat setempat untuk berwirausaha, khususnya bagi ibu-ibu rumah tangga. Diharapkan tidak hanya menumbuhkan perekonomian daerah setempatnya saja tetapi dapat membantu penyerapan tenaga kerja secara nasional. Sedangkan bagi ibu rumah tangga yang mempunyai usaha dapat menambah pendapatan keluarga, mengasah potensi dan kemampuan diri dan membuat ibu rumah tangga menjadi lebih mandiri dan produktif. Usaha makanan dan minuman yang ada di daerah Deketagung umumnya berupa usaha kuliner ayam goreng, bakso, seblak, pecel lele, sempol, aneka minuman dan aneka cemilan atau snack dan juga olshop. Produk USAHA HOMEMADE yang dihasilkan masyarakat di Desa Deketagung mayoritas adalah produk makanan yang adalah buatan sendiri (homemade) yang berskala rumahan dan dikerjakan oleh ibu-ibu rumah tangga. Beberapa produk yang telah ada yaitu sempol ayam, pecel lele, bakso, kerupuk rambak, kerupuk beras dan keripik pisang dan ada juga olshop.

Akan tetapi pertumbuhan USAHA HOMEMADE yang ada pada Desa Deketagung khususnya yang diproduksi oleh ibu-ibu rumah tangga banyak mengalami berbagai macam kendala sehingga kurang optimal. Kendala-kendala tersebut menyebabkan melemahnya daya saing yang dimiliki oleh masing-masing sektor USAHA HOMEMADE sehingga menjadi kurang kompetitif. Beberapa faktor yang dianggap dapat menghambat daya saing USAHA HOMEMADE antara lain banyak pelaku USAHA HOMEMADE di Desa Deketagung masih memproduksi produknya terlalu sederhana dan kurang menarik untuk bersaing dengan produk yang sejenis, baik dalam hal packaging maupun inovasi produk. Selain itu lebih dari 50\% pelaku USAHA HOMEMADE memiliki kendala dalam bidang pemasaran produknya, karena sebagian besar hanya dipasarkan melalui mulut ke mulut dan masih memasarkan produknya di wilayah lokal saja dan secara tradisional. Kurang luasnya pasar yang dapat dijangkau oleh USAHA HOMEMADE di Desa Deketagung berakibat pada omset dan laba yang didapatkan.

Strategi pemasaran dengan menggunakan teknologi tepat guna seperti media sosial dapat menjadi kekuatan utama mendongkrak penjualan produk-produk USAHA HOMEMADE. Pemasaran dengan media teknologi atau pemasaran dengan sistem digital adalah salah satu strategi pemasaran untuk mempromosikan dan memperkenalkan sebuah merek dagang dengan menggunakan media digital. Digital marketing dapat menjangkau konsumen secara tepat waktu, pribadi dan relevan. Pada masa ini media sosial menjadi tools pemasaran berbasis teknologi. Berbagai media sosial terus memperbaiki dan menambah fitur untuk mempermudah penggunanya dalam memasarkan produk. Sebagai contoh, facebook dan instagram memiliki fitur promosi bagi penggunanya yang menjalankan bisnis. Fitur ini memudahkan pelaku bisnis dalam menyebarkan informasi. Fokus masalah dalam pengabdian adalah upaya meningkatkan pangsa pasar dan omset penjualan produk USAHA HOMEMADE di Desa Deketagung yang umumnya diproduksi oleh masyarakat setempat melalui strategi pemasaran yang tepat. Perencanaan strategi pemasaran menjadi salah satu kunci utama kesuksesan sebuah usaha. Begitu pula dalam menjalankan usaha USAHA HOMEMADE di Desa Deketagung. Sebagus apapun kualitas produk yang dihasilkan, tanpa dukungan strategi pemasaran yang tepat maka bias dipastikan tidak banyak orang yang mengetahui keberadaan produk tersebut. 
Berdasarkan latar belakang tersebut maka tujuan kegiatan ini adalah meningkatkan pengetahuan dan keterampilan strategi pemasaran yang tepat khususnya melalui media sosial sehingga dapat meningkatkan omset dan laba penjualan produknya.

\section{METODE PELAKSANAAN}

Metode yang digunakan yaitu dengan melakukan Pelatihan dan pendampingan dalam pengabdian dan pendampingan pada peserta sejumlah 30 orang. Kegiatan akan dimulai dengan mengidentifikasi tingkat pengetahuan dan tingkat ketrampilan terhadap media sosial dengan cara tanya jawab antara pelatih dan pendamping dengan peserta.

Setelah dilakukan tanya jawab, peserta diberikan Pelatihan dan pendampingan dalam pengabdian dan pendampingan tentang pemasaran digital khususnya melalui media sosial . Melanjutkan Pelatihan dan pendampingan dalam pengabdian dan pendampingan dengan materi : cara membuat akun for business, mengunggah foto produk, melakukan edit foto melalui fitur dari facebook dan Instagram, serta memberikan respon ke konsumen..

\section{HASIL DAN PEMBAHASAN}

Pelatihan dan pendampingan dalam pengabdian dan pendampingan akan dilakukan untuk mengedukasi peserta tentang system pemasaran yang lebih mudah dan modern. Pelatihan dan pendampingan dalam pengabdian dan pendampingan meliputi informasi pentingnya teknologi internet untuk mendukung bisnis, bagaimana cara mengakses teknologi internet khususnya media sosial, bagaimana cara berkomunikasi dan bagaimana mencari informasi dengan media sosial. Dengan menggunakan internet akan memungkinkan setiap individu memperoleh informasi apapun dan saling tukar informasi tanpa terkendala.

Berikut adalah grafik hasil Pelatihan dan pendampingan dalam pengabdian dan pendampingan sistem pemasaran digital melalui media sosial . Hasil Kegiatan Pelatihan dan pendampingan dalam pengabdian dan pendampingan Peserta tentang Pemasaran Melalui Media sosial Di Desa Deketagung Kecamatan Sugio dijelaskan pada Grafik 1.

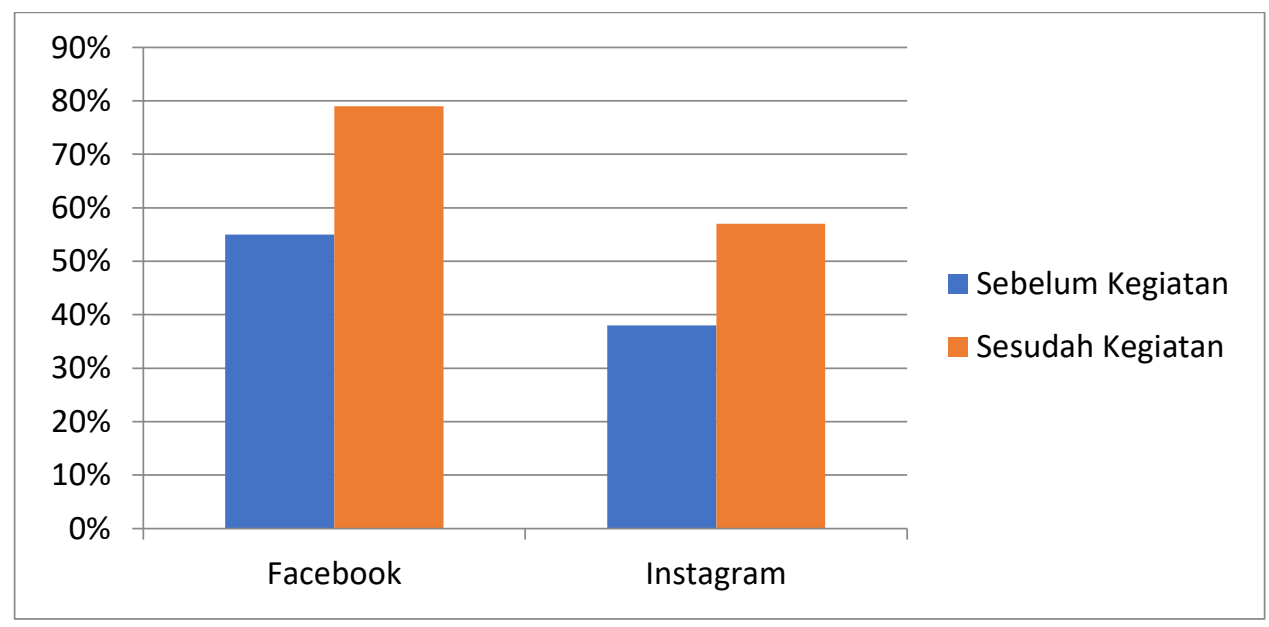

Berdasarkan grafik diatas, pengetahuan dalam penerapan media sosial facebook lebih besar daripada Instagram. Berdasarkan data peserta yang mengikuti Pelatihan dan 
pendampingan dalam pengabdian dan pendampingan ternyata lebih banyak yang mempunyai akun facebook dari pada Instagram. Sehingga dapat diketahui bahwa peserta Pelatihan dan pendampingan dalam pengabdian yang 79\% memiliki akun di facebook dan 57\% memiliki akun instagram, hal ini dikarenakan mereka lebih mudah memahami fitur-fitur di facebook daripada di instagram.

Kesusahan peserta pelatihan dan pendampingan dalam memahami atau membuat media sosial instagram, didominasi oleh penggunaan fitur highlight dan story. Media sosial biasa menjadi wadah kreativitas dan inovasi bagi pengguna. adapun manfaat dari informasi internet sangat membantu pebisnis untuk mengembangkan usahanya (Kosasi, 2014).

Selanjutnya, Pelatihan dan pendampingan dalam pengabdian dan pendampingan dilakukan dengan menggunakan metode experiential learning, yaitu metode yang melibatkan peserta secara aktif di setiap sesi Pelatihan dan pendampingan dalam pengabdian dan pendampingan sehingga peserta dapat belajar dan memahami setiap proses Pelatihan dan pendampingan dalam pengabdian dan pendampingan secara langsung. Kegiatan pengabdian ini dilakukan dengan metode ceramah, tanya jawab, demonstrasi dan praktek langsung. Kegiatan Pelatihan dan pendampingan dalam pengabdian dan pendampingan dilakukan dalam 5 sesi, yaitu :

Sesi pertama, Pelatihan dan pendampingan dalam pengabdian dan pendampingan dalam membuat akun facebook dan akun Instagram untuk bisnisdengan biodata masing-masing peserta yang memiliki usaha. Sebanyak 21 orang atau $79 \%$ peserta sudah memiliki akun facebook pribadi tetapi tidak memiliki akun facebook dan Instagram yang digunakan untuk bisnis. Sisanya sebanyak 9 orang atau $21 \%$ tidak memiliki akun facebook dan Instagram. Selanjutnya, tim pengabdian memberi Pelatihan dan pendampingan dalam pengabdian dan pendampingan dalam membuat akun facebook dan Instagram untuk bisnis, Contoh facebook untuk bisnis dapat dilihat dalam gambar berikut :

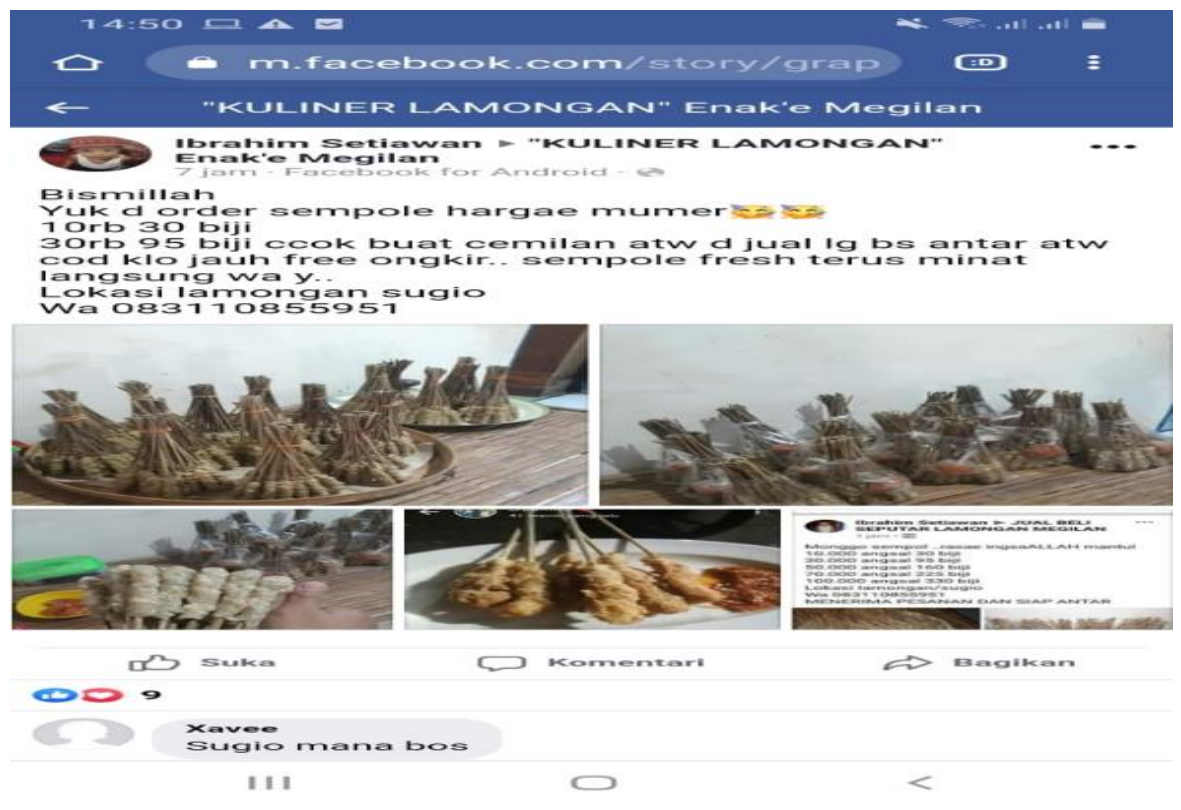

Gambar 1. Contoh Facebook untuk bisnis 
Sesi kedua yaitu Pelatihan dan pendampingan dalam pengabdian membuat konten bisnis di media sosial Sesi ketiga, Pelatihan dan pendampingan dalam pengabdian memposting konten promosi produk dan memberikan keterangan atau caption yang menarik konsumen. Contoh tampilan konten produk dapat dilihat berikut ini:

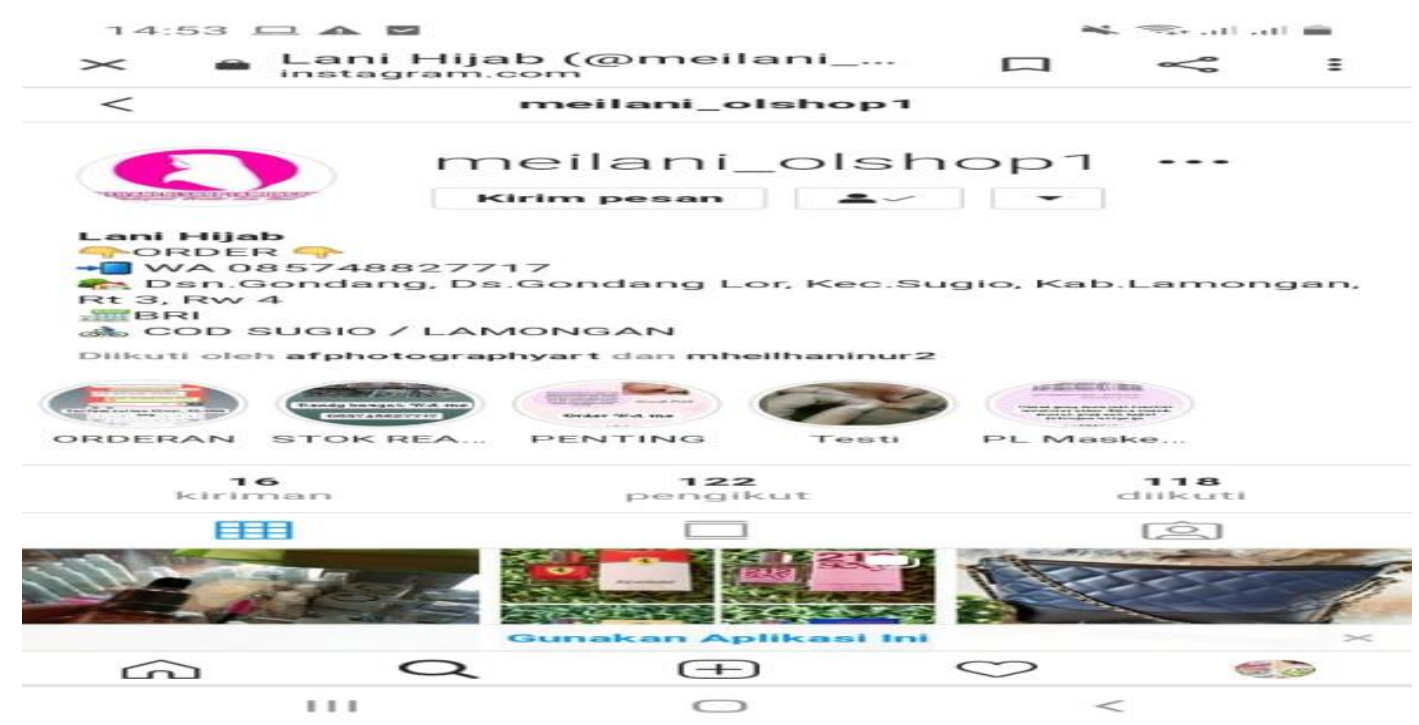

Gambar 2. Contoh Akun Instagram dan Tampilan Foto Produk untuk Promosi

Sesi keempat, yaitu Pelatihan dan pendampingan dalam pengabdian cara berkomunikasi dengan pelanggan facebook dan Instagram. Materi yang diberikan yaitu cara mempromosikan produk ke konsumen agar lebih menarik dan cara merespon pesan dari konsumen yang baik dan benar.

Keberhasilan Pelatihan dan pendampingan dalam pengabdian ini dipengaruhi oleh banyak hal, antara lain kompetensi trainer dalam memberikan materi, kelengkapan sarana dan peralatan untuk melakukan praktek, antusiasme peserta saat mengikuti Pelatihan dan pengabdian, hal ini diketahui dari hasil observasi selama Pelatihan dan pendampingan dalam pengabdian berlangsung.

Berdasarkan hasil analisis dari uji pretest dan posttest yang dilakukan terhadap 30 orang warga Desa Deketagung didapatkan hasil nilai sig (2-tailed) $=0,013$ dengan taraf signifikansi $0,000(\mathrm{p}<0,05)$ skor rerata pretest 79 menjadi skor rerata posttest 150 . Perubahan angka pretest dan post test amenunjukan bahwa adanya perubahan yang signifikan pada tingkat pemahaman dan keterampilan menggunakan media sosial sebagai alat pemasaran produk. Terbukti bahwa Pelatihan dan pendampingan dalam pengabdian sangat efektif dalam meningkatkan pemahaman dan ketrampilan seseorang (Mangkuprawira, 2004).

Peserta Pelatihan dan pendampingan dalam pengabdian terlihat aktif dalam memberikan argument terhadap materi Pelatihan dan pendampingan dalam pengabdian melalui pertanyaanpertanyaan. Selain itu, peserta juga aktif terlibat dalam praktek dan diskusi yang diadakan. Peserta juga memberikan penilaian terhadap proses Pelatihan dan pendampingan dalam pengabdian yang berlangsung pada akhir proses Pelatihan dan pengabdian. Evaluasi Pelatihan dan pendampingan dalam pengabdian yang terdiri dari evaluasi terhadap materi Pelatihan dan pengabdian, pelatih. Menurut peserta Pelatihan dan pengabdian, materi yang diberikan sesuai dengan kebutuhan untuk meningkatkan pemasaran produk mereka. 


\section{KESIMPULAN DAN SARAN}

Pelatihan dan pendampingan dalam pengabdian pemasaran produk melalui media sosial yang telah dijalankan akan mampu meningkatkan pengetahuan dan kemampuan peserta dalam memanfaatan media sosial sebagai alat pemasaran yang secara modern. Dengan menggunakan media sosial sebagai alat pemasarannya akan mampu memperluas jangkauan pemasaran sehingga mampu meningkatkan omset penjualan produk.

Terimakasih kepada Kepala Desa Deketagung selaku mitra kegiatan Pengabdian pada Masyarakat, dan seluruh UMKM Desa Deketagung, Kecamatan Sugio, Kabupaten Lamongan yang telah mengikuti kegiatan pengabdian masyarakat. Terimakasih kepada segenap pihakpihak yang telah membantu dalam proses kegiatan pengabdian pada masyarakat ini.

\section{DAFTAR PUSTAKA}

Khairani, Z., (2018). Efektivitas Promosi Melalui Instagram Pada UMKM Sektor Makanan Dan Minuman Di Kota Pekanbaruefektivitas Promosi Melalui Instagram Pada Umkm Sektor Makanan Dan Minuman Di Kota Pekanbaru.Jurnal Benefit. Vol.3, No.1. 239-247.

Kosasi, S., (2014). Pembuatan Sistem Informasi Penjualan Berbasis Web Untuk Memperluas Pangsa Pasar. Prosiding, SNATIF Ke-1 Tahun 2014. Fakultas Teknik -Universitas Muria Kudus, hal 225-232.

Mangkuprawira, S., (2004). Manajemen Sumber Daya Manusia Strategi, Jakarta Selatan : Ghalia Indonesia.

Noning, V. (2016). Pergeseran Pemanfaatan Instagram Sebagai Media Bisnis Online (Studi Kasus pada Akun @Schonehazzle). Jurnal Ilmu Komunikasi, Vol.12, No.12. hal.1225.

Primiana, I., (2009). Menggerakkan Sektor Riil UKM \& Industri. Bandung: Alfabeta.

Riandhita, E.W, (2020). Pelatihan Pemasaran Produk Homemade Melalui Sosial Media, JPPM LPIP UMP, Vol.4, No.1, 1-5.

Sudaryanto., (2012). Strategi Pemberdayaan UMKM Menghadapi Pasar Bebas Asean. Jurnal Ekonomi Akuntansi dan Manajemen, 1(2).

Supriyanto. (2004). Pemberdayaan Teknologi Informasi untuk Keunggulan Bisnis. Jurnal Ekonomi \& Pendidikan, 2 (1), 99-112.

websindo.com diakses pada Oktober 2019 